\title{
Sensitive Voltammetric Determination of Captopril Using a Carbon Paste Electrode Modified with $\mathrm{Nano}_{-} \mathrm{TiO}_{2} /$ Ferrocene Carboxylic Acid
}

\author{
Jahan Bakhsh RAOOF*, Reza OJANI, Mehdi BAGHAYERI \\ Electroanalytical Chemistry Research Laboratory, Department of Analytical Chemistry, Faculty of Chemistry, \\ Mazandaran University, Babolsar 47416-95447, Iran
}

\begin{abstract}
A carbon paste electrode (CPE) modified with ferrocene carboxylic acid $(\mathrm{FcCA})$ and $\mathrm{TiO}_{2}$ nanoparticles was constructed by incorporating $\mathrm{TiO}_{2}$ nanoparticles and ferrocene carboxylic acid into the carbon paste matrix. The electrochemical behavior of captopril (CAP) at the surface of the modified electrode was investigated using electroanalytical methods. The modified electrode showed excellent electrocatalytic activity for the oxidation of CAP in aqueous solutions at physiological $\mathrm{pH}$ values. Cyclic voltammetric curves showed that the oxidation of CAP at the surface of the modified electrode reduced its overpotential by more than $290 \mathrm{mV}$. The modified electrode was used for detecting captopril using cyclic voltammetry and square wave voltammetry techniques. A calibration curve in the range of 0.03 to 2400 $\mu \mathrm{mol} / \mathrm{L}$ was obtained that had a detection limit of $0.0096 \mu \mathrm{mol} / \mathrm{L}(3 \sigma)$ under the optimized conditions. The modified electrode was successfully used for the determination of captopril in pharmaceutical and biological samples.
\end{abstract}

Key words: electrocatalysis; modified electrode; nano- $\mathrm{TiO}_{2}$; ferrocene carboxylic acid captopril; cyclic voltammetry

CLC number: O643 Document code: A

Received 7 June 2011. Accepted 10 August 2011.

*Corresponding author. Tel: +98-112-5342392; Fax:+98-112-5342350; E-mail: j.raoof@umz.ac.ir

English edition available online at Elsevier ScienceDirect (http://www.sciencedirect.com/science/journal/18722067).

Captopril (CAP), (S)-1-(3-mercapto-2-methyl-1-oxopropyl)-1-proline, is the first discovered orally active angiotensin-converting enzyme (ACE) inhibitor. The CAP is used for the treatment of hypertension, congestive heart failure, and left ventricular dysfunction after myocardial infarction [1]. It contains a sulphydryl group and binds readily to albumin and other plasma proteins [2]. Scheme 1 shows the structural formulae of CAP. Like other thiols, CAP undergoes rapid oxidation to disulphide metabolites both in vitro and in vivo $[3,4]$. In cells, disulphide metabolites are reduced to the free thiol and can act as a reservoir for free CAP. Only the free CAP is pharmacologically active [2]. Dietary thiols such as CAP, glutathione (GSH), and cysteine (CYS) with a sulphydryl functional group can regulate cell and tissue thiol levels by different models [5-7]. We can say that different biological thiols regulate human health through different mechanisms. Several analytical methods have been proposed for the determination of CAP and other thiol drugs of pharmaceutical interest, such as penicilamine and $N$-acetyl-1-cysteine. These methods include chemiluminometry [8,9], spectrometry [10,11], fluorimetry [12], polarography $[13,14]$, and chromatographic techniques $[15,16]$. However, spectrophotometric methods need thiol derivatization. Although the results obtained from chromatographic methods are reliable with respect to selectivity, their separations are time consuming and they need expen- sive instruments. Electrochemical methods have proved useful for the sensitive and selective determination of various analytes. These methods do not require tiresome pretreatment and only use limited pre-separation, and consequently they reduce the cost of measurements [17-19]. Several modified electrodes have been successfully developed for the detection of CAP using graphite [20,21], a selective membrane electrode [20] and a boron-doped diamond thin film [22] as the working electrode. Among the most successful mediators, ferrocene and its derivatives have been of interest because of their useful properties such as a low relative molar mass, fast response, can be regenerated at a low potential and were stable in both oxidized and reduced forms [23]. In addition, the application of various nanomaterials for the modification of electrode surfaces and improvement of their electrochemical characteristics have been studied in recent years [24]. Nano- $\mathrm{TiO}_{2}$ has a wide range of technological applications as gas sensors, photo and thermal catalysts, and photoelectrocatalysts due to its excellent chemical and photochemical stability, non-toxicity, and capability for the photooxidative destruction of most organic pollutants [25-28]. Nano- $\mathrm{TiO}_{2}$ also has excellent physical and chemical properties and has been used in coating, sensor, solar cell, and photocatalyst applications [29,30]. In recent years, carbon paste electrodes modified with a mixture of nanoparticles and substances for 
electron transmission have been shown to give considerable improvements in the electrochemical activity of some biologically important compounds [23,24]. Recently we have developed a novel and sensitive electrochemical sensor based on the incorporation of $\mathrm{TiO}_{2}$ nanoparticles and ferrocene carboxylic acid into carbon paste matrix for the determination of glutathione, which is a biological compound in hemolyzed erythrocyte [31]. The present work used this kind of electrode as a simple and sensitive electrochemical sensor with nanopores that has the advantages of low cost, high sensitivity, reproducibility, simplicity, and that can be easily preserved for a long time.

The electrochemical determination of CAP using a carbon paste electrode modified with ferrocene carboxylic acid $/ \mathrm{TiO}_{2}$ nanoparticles has not been reported. For glutathione and captopril in the same sample, this sensor can be used for their determination in suitable samples. In order to further improve the sensitivity of the modified electrode, square wave voltammetry (SWV), which is a much better technique for practical analysis [32], was successfully used for the determination of CAP in practical samples.

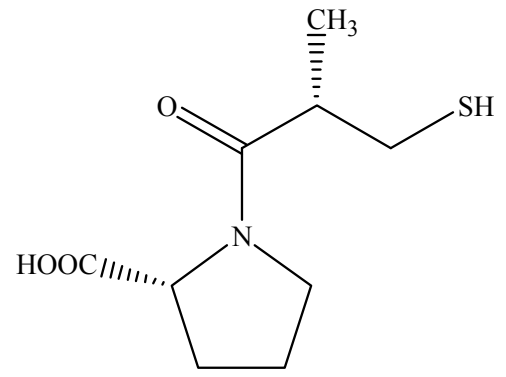

Scheme 1. The structural formulae of CAP.

This work fabricated a $\mathrm{FcCA} / \mathrm{TiO}_{2}$ nanoparticle-modified carbon paste electrode $\left(\mathrm{FcCA} / \mathrm{TiO}_{2} / \mathrm{CPE}\right)$ as a voltammetric sensor for the determination of low concentrations of CAP in real-life samples. The presence of nano- $\mathrm{TiO}_{2}$ led to an enhancement in the electrochemical oxidation of CAP in buffered solution $(\mathrm{pH}=7.0)$. The experimental conditions for the oxidation reaction were optimized, and the final modified electrode allowed the successful determination of trace levels of CAP.

\section{Experimental}

\subsection{Materials}

CAP and ferrocene carboxylic acid (FcCA) were obtained from Fluka. Nano- $\mathrm{TiO}_{2}$ particles were purchased from Sharif Industrial University, Tehran, Iran. Phosphate buffered solutions (PBS) of $0.1 \mathrm{~mol} / \mathrm{L}$ for different $\mathrm{pHs}$ were prepared by mixing stock solutions of $0.1 \mathrm{~mol} / \mathrm{L} \mathrm{H}_{3} \mathrm{PO}_{4}$, $\mathrm{NaH}_{2} \mathrm{PO}_{4}, \mathrm{Na}_{2} \mathrm{HPO}_{4}$, and $\mathrm{Na}_{3} \mathrm{PO}_{4}$. High viscosity paraffin (density $=0.88 \mathrm{~g} / \mathrm{cm}^{3}$ ) from Fluka was used as the pasting liquid for the carbon paste electrode. Graphite powder (particle diameter $=0.1 \mathrm{~mm}$ ) from Merck and potassium chloride from Fluka were used as the working electrode (WE) substrate and the supporting electrolyte, respectively. The pharmaceutical and biological samples used in this work were obtained from Dr. Safiri Medical Diagnostic Laboratory, Babolsar, Iran and Daro Pakhsh Pharmaceutical Mfg. Co., Tehran, Iran, respectively. Double distilled water was used in all the experiments. All the other regents were analytical grade.

\subsection{Preparation of the working electrode}

Diethyl ether was added to a mixture of $1 \%(\mathrm{~m} / \mathrm{m}) \mathrm{FcCA}$, $20 \%(\mathrm{~m} / \mathrm{m})$ nano- $\mathrm{TiO}_{2}$, and graphite powder. After hand mixing with a mortar and pestle, the solvent was evaporated with stirring. A 1:1 $(\mathrm{m} / \mathrm{m})$ ratio of the resulting mixture and paraffin was mixed until a uniformly wetted paste was obtained. The paste was packed into the end of a glass tube (internal radius $1.0 \mathrm{~mm}$ and $10 \mathrm{~cm}$ length). An electrical connection was made by a copper wire lead fitted into the glass tube. When necessary, a new surface was obtained by pushing an excess of paste out of the tube and polishing it on weighing paper. An unmodified carbon paste electrode was prepared in the same way, but without adding FcCA and nano- $\mathrm{TiO}_{2}$.

\subsection{Apparatus}

Voltammetric measurements were carried out using a computerized potentiostat and galvanostat ( $\mu$-Autolab TYPE III, Eco Chemie BV, Netherlands) that was connected to a personal computer. The experimental condition for the voltammetric measurements was controlled with a General Purpose Electrochemical System (GPES) software. All electrochemical studies were performed at $25 \pm 2{ }^{\circ} \mathrm{C}$ with a three-electrode assembly with a carbon paste working electrode (unmodified or modified), an $\mathrm{Ag} / \mathrm{AgCl} / \mathrm{KCl}$ (3 mol/L) electrode as the reference electrode, and a platinum wire counter electrode. A digital pH meter (Ion Analyzer 250, Corning) was used to read the $\mathrm{pH}$ of the buffered solutions.

\section{Results and discussion}

\subsection{The effect of $\mathrm{pH}$ on the oxidation peak current}

$\mathrm{pH}$ is one of the parameters that affect the electrode response in biological sample determination. Figure 1 (a) shows the electrochemical behavior of CAP in $0.1 \mathrm{~mol} / \mathrm{L}$ phosphate buffered solution with various $\mathrm{pHs}(5.0<\mathrm{pH}<8.0)$ at the surface of $\mathrm{FcCA} / \mathrm{TiO}_{2} / \mathrm{CPE}$ using cyclic voltammetry. 

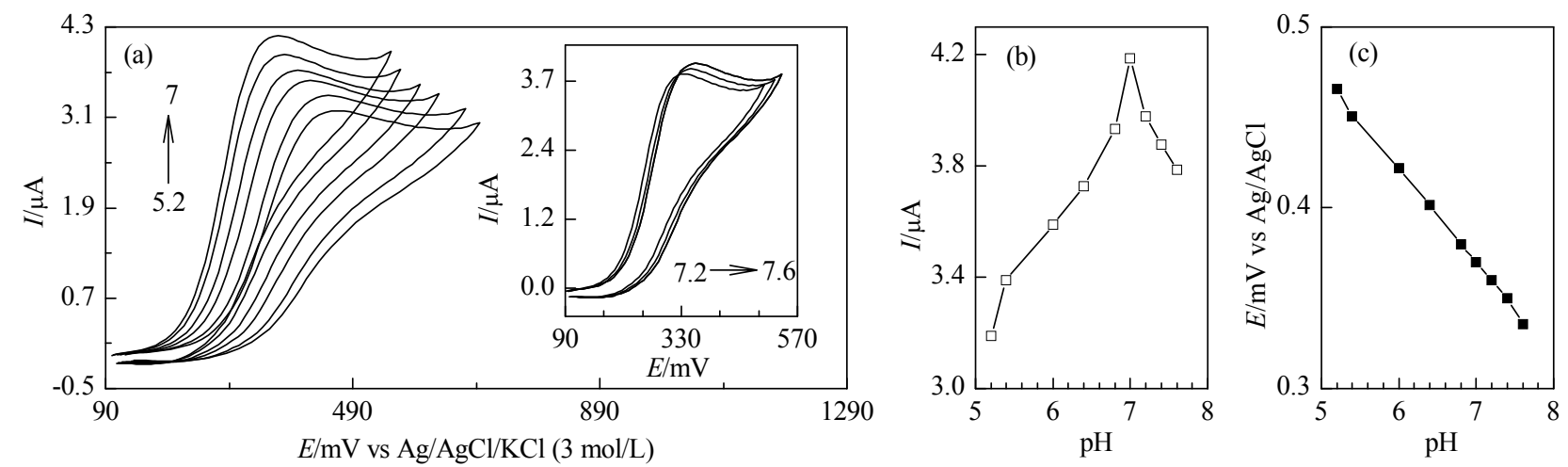

Fig. 1. Cyclic voltammetric response from $\mathrm{FcCA} / \mathrm{TiO}_{2} / \mathrm{CPE}$ in $1.0 \mu \mathrm{mol} / \mathrm{L} \mathrm{CAP}$ solution at different $\mathrm{pH}$ values (from 5.2-7.6) and the scan rate 25 $\mathrm{mV} / \mathrm{s}(\mathrm{a})$; variation of the anodic peak current in the cyclic voltammograms of $1.0 \mu \mathrm{mol} / \mathrm{L} \mathrm{CAP}$ at the surface of $\mathrm{FcCA} / \mathrm{TiO} / 2 \mathrm{CPE}$ (b); influence of the solution $\mathrm{pH}$ on the peak potential for $1.0 \mu \mathrm{mol} / \mathrm{L} \mathrm{CAP} \mathrm{(c).}$

It can be seen that the anodic peak current of CAP reaches a maximum value at $\mathrm{pH}=7.0$, and then decreases gradually as $\mathrm{pH}$ increases (Fig. 1(b)). Therefore, $\mathrm{pH}=7.0$ was chosen as optimum $\mathrm{pH}$ for the following electrochemical detection of CAP. Also, the anodic peak potential of CAP at the surface of $\mathrm{FcCA} / \mathrm{TiO}_{2} / \mathrm{CPE}$ shifts to less positive values with increasing $\mathrm{pH}$ of the buffered solution (Fig. 1(c)). The slope $52.5 \mathrm{mV} / \mathrm{pH}$ indicated that electron transfer was accompanied by an equal number of protons in electrode reaction of CAP [33].

\subsection{Electrocatalytic oxidation of captopril}

The results of our previous works showed that CPEs modified with ferrocene and its derivatives have a catalytic effect in the electro-oxidation of biologically important thiol compounds [34,35]. The important catalytic role of the modifier caused a lowering of the anodic overpotential. The electrochemical properties of FcCA spiked in carbon paste have been studied by cyclic voltammetry in previous works [36,37]. The electrochemical behavior of the present modified electrode was in agreement with the previous results.

Figure 2 shows the cyclic voltammetric responses from the electrochemical oxidation of $1.0 \mu \mathrm{mol} / \mathrm{L} \mathrm{CAP}$ at the surface of the different electrodes, and the anodic peak potentials for the oxidation of CAP are shown in Table 1. The best electrocatalytic effect for CAP oxidation was at the $\mathrm{FcCA} / \mathrm{TiO}_{2} / \mathrm{CPE}$ (curve (6)). The peak potential of CAP oxidation at the $\mathrm{FcCA} / \mathrm{TiO}_{2} / \mathrm{CPE}$ (curve (6)) was shifted to be less by $370 \mathrm{mV}$ in comparison with that at the nano- $\mathrm{TiO}_{2} / \mathrm{CPE}$ (curve (3)) and CPE (curve (2)). Similarly, the anodic peak current for the oxidation of CAP at the $\mathrm{FcCA} / \mathrm{TiO}_{2} / \mathrm{CPE}$ (curve (6)) was significantly increased in comparison with that at the FcCA/CPE (curve (5)). These data clearly showed that the combination of $\mathrm{TiO}_{2}$ nanoparticles and mediator (FcCA) have improved the catalysis of $\mathrm{CAP}$ oxidation. The $\mathrm{FcCA} / \mathrm{TiO}_{2} / \mathrm{CPE}$ in $0.1 \mathrm{~mol} / \mathrm{L}$ phos- phate buffer ( $\mathrm{pH}$ 7.0) and without CAP in the solution exhibited a well-behaved redox reaction (curve (4)). The anodic peak current at the $\mathrm{FcCA} / \mathrm{TiO}_{2} / \mathrm{CPE}$ with the addition of $1.0 \mu \mathrm{mol} / \mathrm{L} \mathrm{CAP}$ was much enhanced (curve (6)), indicating that the $\mathrm{FcCA} / \mathrm{TiO}_{2} / \mathrm{CPE}$ improved the electrochemical activity for the oxidation of CAP.

In the impedance spectroscopy study in our previous

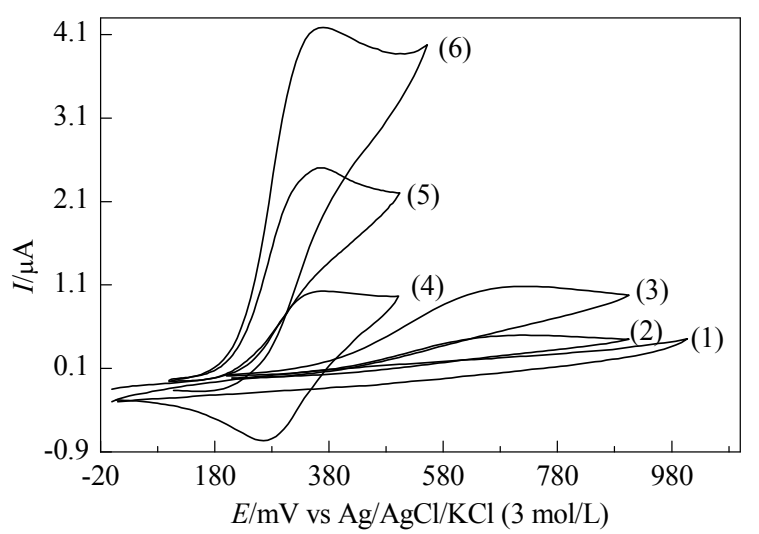

Fig. 2. CVs of CPE in the absence of CAP (1), and in the presence of $1.0 \mu \mathrm{mol} / \mathrm{L} \mathrm{CAP}$ at the surface of $\mathrm{CPE}(2)$ and nano- $\mathrm{TiO}_{2} / \mathrm{CPE}$ (3), respectively, in the absence of $\mathrm{CAP}$ at the surface of $\mathrm{FcCA} / \mathrm{TiO}_{2} / \mathrm{CPE}$ and (4), and in the presence of CAP at the surface of FcCA/CPE (5) and $\mathrm{FcCA} / \mathrm{TiO}_{2} / \mathrm{CPE}(6)$, respectively. All experiments were done with a $0.1 \mathrm{~mol} / \mathrm{L}$ phosphate buffer solution $(\mathrm{pH} 7.0)$ at scan rate of $25 \mathrm{mV} / \mathrm{s}$.

Table 1 The anodic peak potential for the oxidation of CAP at the surface of different electrodes

\begin{tabular}{lcc}
\hline Solution & Electrode & $E_{\mathrm{p}} / \mathrm{mV}$ \\
\hline $0.1 \mathrm{~mol} / \mathrm{L}$ phosphate buffer & $\mathrm{CPE}$ & - \\
solution (base solution) & & \\
Base solution $+1.0 \mu \mathrm{mol} / \mathrm{L} \mathrm{CAP}$ & $\mathrm{CPE}$ & 733 \\
Base solution $+1.0 \mu \mathrm{mol} / \mathrm{L} \mathrm{CAP}$ & $\mathrm{TiO}_{2} / \mathrm{CPE}$ & 733 \\
Base solution & $\mathrm{FcCA}_{\mathrm{TiO}} / \mathrm{CPE}$ & - \\
Base solution $+1.0 \mu \mathrm{mol} / \mathrm{L} \mathrm{CAP}$ & $\mathrm{FcCA} / \mathrm{CPE}$ & 363 \\
Base solution $+1.0 \mu \mathrm{mol} / \mathrm{L} \mathrm{CAP}$ & $\mathrm{FcCA} / \mathrm{TiO} / \mathrm{CPE}$ & 363 \\
\hline
\end{tabular}


work [31], the charge transfer resistance for CPE spiked when the amount of nano- $\mathrm{TiO}_{2}$ was decreased. Therefore, we suggest that the addition of nano- $\mathrm{TiO}_{2}$ to $\mathrm{FcCA} / \mathrm{CPE}$ caused the effective surface area of the electrode for the electrooxidation of CAP to increase, hence, the anodic current was increased by the adding of $\mathrm{TiO}_{2}$ nanoparticles. The resulting peak (curve (6)) indicated a strong electrocatalytic effect on the electrooxidation of CAP at the surface of $\mathrm{FcCA} / \mathrm{TiO}_{2} / \mathrm{CPE}$. From the slope obtained from the plot of peak potential of CAP $\left(\mathrm{p} K_{\mathrm{a}}=3.7\right.$ and 9.8$)$ versus $\mathrm{pH}$ in section 2.1, we propose the following mechanism for the oxidation of CAP [38] at the surface of $\mathrm{FcCA} / \mathrm{TiO}_{2} / \mathrm{CPE}$ :

$$
\begin{aligned}
& \mathrm{CAPSH} \leftrightarrow \mathrm{CAPS}^{-}+\mathrm{H}^{+} \\
& \mathrm{CAPS}^{-} \rightarrow \text { CAPS } \cdot+\mathrm{e}^{-} \\
& \text {2CAPS } \rightarrow \text { CAPSSCAP }
\end{aligned}
$$

\subsection{Effect of scan rate on the peak current and peak potential}

Figure 3 shows the cyclic voltammograms obtained from FcCA/TiO $/ 2$ CPE in buffered solution $(\mathrm{pH}=7.0)$ in the presence of $1.0 \mu \mathrm{mol} / \mathrm{L} \mathrm{CAP}$ at scan rates of $10-100 \mathrm{mV} / \mathrm{s}$. At high scan rates, the cathodic current increased with an increase of $v$ because the short time-scale of the experiments did not give enough time for the catalytic reaction between $\mathrm{FcCA}^{+}$, reduced by the electrooxidation of $\mathrm{FcCA}$, and CAP to take place completely. We have checked the dependence of the peak current on the scan rate. A linear correlation between the peak currents and the square root of the scan rate was obtained with a correlation equation of $y=$ $0.3162 x+0.8444$, and $R^{2}=0.9795$. This indicated that the redox process was diffusion controlled (Fig. 3(b)).

As the potential sweep rate increased, the oxidation peak potentials shifted to more positive values, confirming the

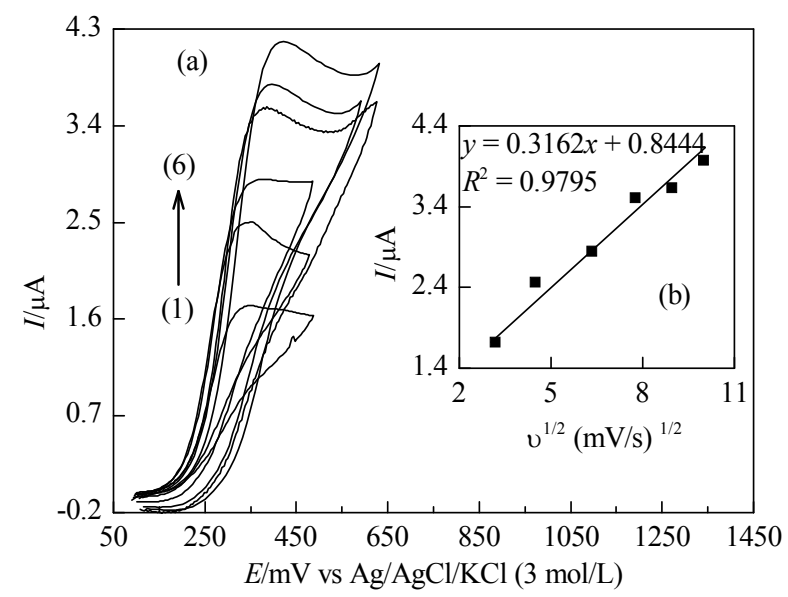

Fig. 3. Cyclic voltammograms of $\mathrm{FcCA} / \mathrm{TiO}_{2} / \mathrm{CPE}$ in the presence of $1.0 \mu \mathrm{mol} / \mathrm{L} \mathrm{CAP}$ in $0.1 \mathrm{~mol} / \mathrm{L}$ phosphate buffer solution $(\mathrm{pH}=7.0)$ at various scan rates (a): (1) 10, (2) 20, (3) 40, (4) 60, (5) 80, and (6) 100 $\mathrm{mV} / \mathrm{s}$; (b) plot of $I$ versus $v^{1 / 2}$. limitation of the kinetics [39] of the electrochemical reaction. Figure 4 shows a Tafel plot that was drawn from the data taken from the rising part of the current-voltage curve recorded at a scan rate of $10 \mathrm{mV} / \mathrm{s}$. This part of the voltammogram, known as a Tafel region [40], is affected by the electron transfer kinetics between the CAP and the electrode surface. Under this condition, the number of electrons involved in the rate determining step can be estimated from the slope of the Tafel plot. A slope of $0.1574 \mathrm{~V} /$ decade was obtained, indicating a one-electron transfer to be rate limiting. A transfer coefficient of $\alpha=0.62$ was obtained. The same experiment was also done on a FcCA/CPE in the presence of CAP and the value of $\alpha$ was calculated to be 0.41 . These $\alpha$ values obtained clearly showed that electron-transfer process was greatly enhanced by the presence of $\mathrm{TiO}_{2}$ nano particles at the surface of $\mathrm{FcCA} / \mathrm{TiO}_{2} / \mathrm{CPE}$.

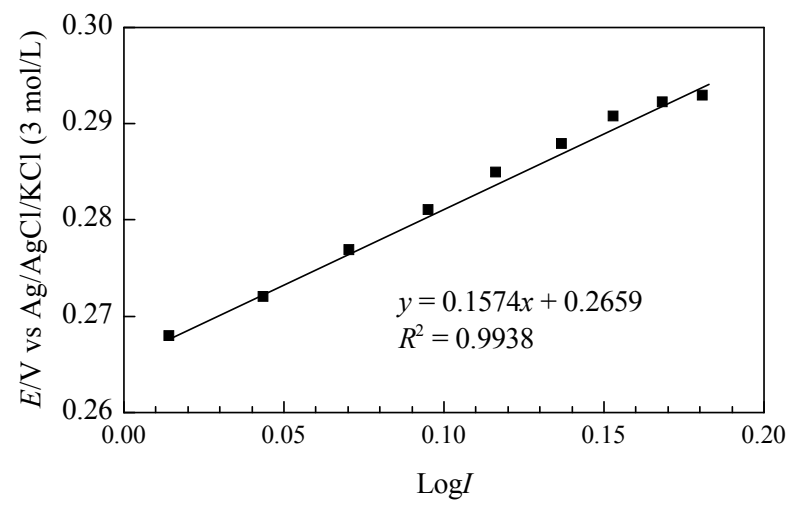

Fig. 4. Tafel plot derived from the rising part of the voltammogram recorded for the electrocatalytic oxidation of CAP at a scan rate of 10 $\mathrm{mV} / \mathrm{s}$ at the surface of $\mathrm{FcCA} / \mathrm{TiO}_{2} / \mathrm{CPE}$ obtained from data of Fig. 3.

\subsection{Chronoamperometric Measurements}

We employed the double potential step chronoamperometry method for the investigation of the electrodic processes at the modified electrode. Figure 5(a) shows the current-time curves of the modified electrode obtained by setting the working electrode potential to $420 \mathrm{mV}$ (at the first potential step) and $300 \mathrm{mV}$ (at the second potential step) vs $\mathrm{Ag} / \mathrm{AgCl} / \mathrm{KCl}(3 \mathrm{~mol} / \mathrm{L})$ for various concentrations of CAP in phosphate buffered solutions $(\mathrm{pH}=7.0)$. As can be seen, there was no net cathodic current corresponding to the reduction of $\mathrm{FcCA}^{+}$to $\mathrm{FcCA}$ in the presence of $\mathrm{CAP}$. The forward and backward potential steps in the chronoamperometry on the modified electrode in the blank buffered solution showed very symmetrical chronoamperograms with an equal charge consumed for the oxidation and reduction of the $\mathrm{FcCA} / \mathrm{FcCA}^{+}$redox system in the modified electrode matrix (Fig. 5(a)). However, in the presence of CAP, the charge value associated with the forward potential step in the chronoamperometry was significantly larger than that 

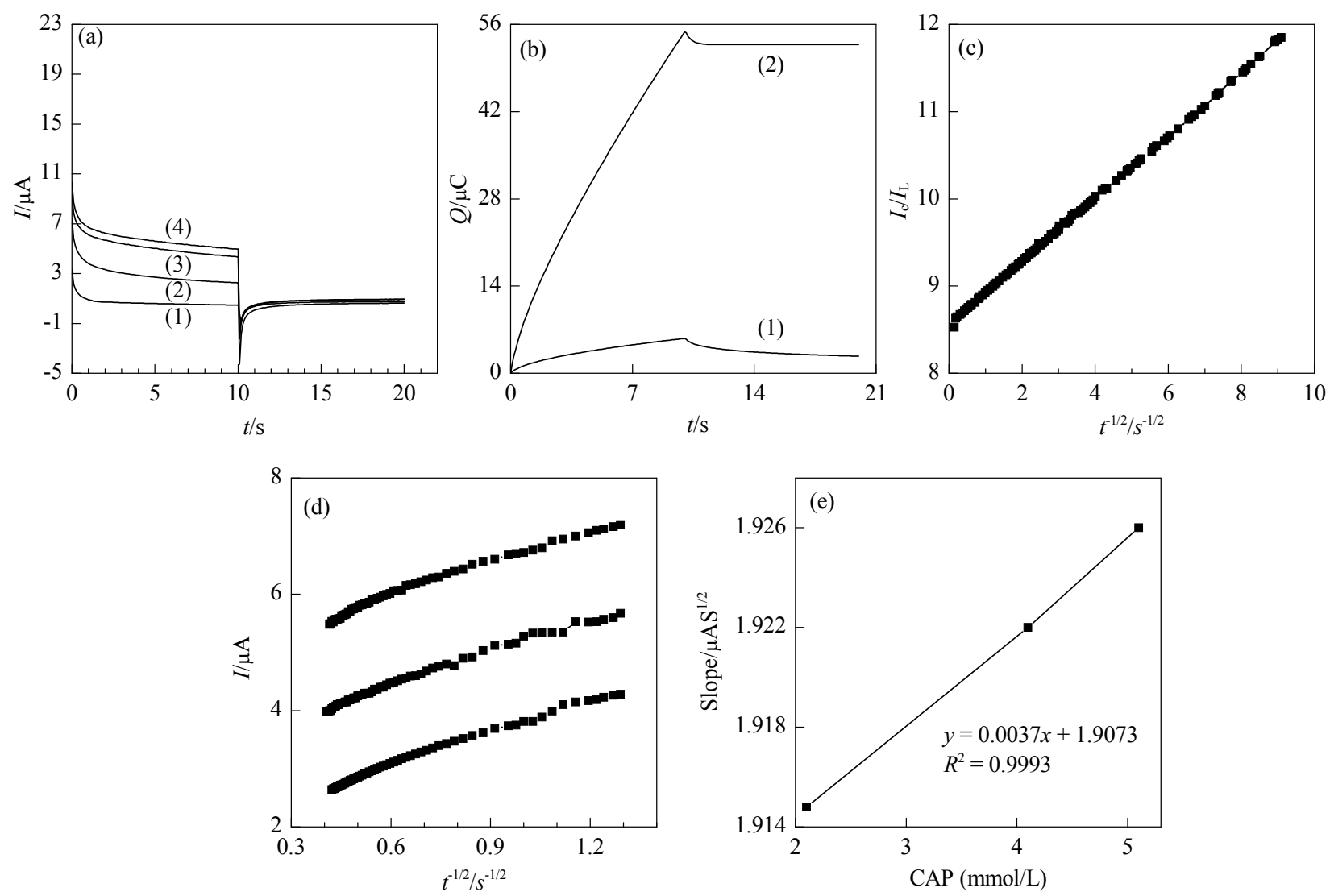

Fig. 5. (a) Chronoamperograms obtained at the $\mathrm{FcCA} / \mathrm{TiO}_{2} / \mathrm{CPE}$ in $0.1 \mathrm{~mol} / \mathrm{L}$ phosphate buffer solution in the absence (1) and presence of (2) 2.0 , (3) 4.0 and (4) $5.0 \mu \mathrm{mol} / \mathrm{L}$ of CAP in phosphate buffer solution; (b) Charge-time curves in the absence (1) and presence of 2.0 $\mu$ mol/L CAP (2); (c) Dependence of $I_{\mathrm{C}} / I_{\mathrm{L}}$ on $t^{1 / 2}$ derived from the chronoamperograms of (1) and (2) in (a); (d) Plots of $I$ versus $t^{-1 / 2}$ obtained from chronoamperograms (2)-(4) in (a); (e) Plot of the slope of the straight lines versus CAP concentration.

observed for the backward potential step chronoamperometry (Fig. 5(b)).

Figure 5(d) shows the current as a function of the inverse of the square root of time. This curve was derived from the chronoamperometric curves of a $\mathrm{FcCA} / \mathrm{TiO}_{2} / \mathrm{CPE}$ in 0.1 $\mathrm{mol} / \mathrm{L} \mathrm{Na}_{2} \mathrm{HPO}_{4}-\mathrm{NaH}_{2} \mathrm{PO}_{4}(\mathrm{pH}=7.0)$ buffer solutions. The current $(I)$ was proportional to the inverse of the square root of the transition time $(t)$. Since the mass transfer of CAP was still under diffusion control when the nano- $\mathrm{TiO}_{2} / \mathrm{FcCA}$ carbon paste electrode was used, its diffusion coefficient can be calculated by Cottrell's equation [41]

$$
I=n F A D_{\text {app }}^{1 / 2} C_{\mathrm{b}} \pi^{-1 / 2} t^{-1 / 2}
$$

where $D_{\text {app }}$ and $C_{\mathrm{b}}$ were the apparent diffusion coefficient $\left(\mathrm{cm}^{2} / \mathrm{s}\right)$ and bulk concentration $(\mathrm{mol} / \mathrm{ml})$, respectively. Figure 5(e) shows the fitted experimental plots for different concentrations of CAP in the range of $2.0-5.0 \mu \mathrm{mol} / \mathrm{L}$. The mean value of $D_{\text {app }}$ was $1.17 \times 10^{-6} \mathrm{~cm}^{2} / \mathrm{s}$ from the slopes of the resulting straight lines plotted versus the CAP concentration (Fig. 5(d)). The results obtained clearly showed that the oxidation of CAP can be catalyzed by the mediator on the surface of $\mathrm{FcCA} / \mathrm{TiO}_{2} / \mathrm{CPE}$. Also, the average value of the catalytic rate constant, $k(\mathrm{ml} /(\mathrm{mol} \cdot \mathrm{s}))$, of the reaction between analyte and mediator was calculated to be $2.1 \times 10^{7}$ $\mathrm{ml} /(\mathrm{mol} \cdot \mathrm{s})$ using the equation reported by Galus [42]:

$$
I_{\mathrm{C}} / I_{\mathrm{L}}=\pi^{1 / 2} \gamma^{1 / 2}=\pi^{1 / 2}\left(k C_{\mathrm{b}} t\right)^{1 / 2}
$$

where $I_{\mathrm{C}}$ is the catalytic current of CAP at the $\mathrm{FcCA} / \mathrm{TiO}_{2} / \mathrm{CPE}, I_{\mathrm{L}}$ is the limited current in the absence of $\mathrm{CAP}, C_{\mathrm{b}}$ is the bulk concentration of CAP, and $t(\mathrm{~s})$ is the time elapsed (Fig. 5(c)). This result prove the capability of using nano- $\mathrm{TiO}_{2}$ and $\mathrm{FcCA}$ for analyzing the electrocatalytic oxidation of CAP at the surface of $\mathrm{FcCA} / \mathrm{TiO}_{2} / \mathrm{CPE}$.

\subsection{Electrocatalytic determination of CAP}

The electrooxidation of CAP was studied at $\mathrm{pH}=7.0$ at the surface of $\mathrm{FcCA} / \mathrm{TiO}_{2} / \mathrm{CPE}$ using square wave voltammetry. SWV is a large amplitude differential technique in which a waveform composed of a symmetrical square wave is applied to the working electrode. It has excellent sensitivity due to the fact that the net current is larger than either the forward or reverse components (since the difference between these and the background current can be omitted). The sensitivity is higher than that of differential pulse voltammetry in which the reverse current is not used [43]. 
Our sensor showed a large CAP linear response range from $3.0 \times 10^{-8}$ to $2.4 \times 10^{-3} \mathrm{~mol} / \mathrm{L}$ (Fig. 6(a)). The dependence of the peak current on CAP concentration is shown in insets (b) and (c) in Fig. 6. These insets clearly showed that the plot of peak current versus CAP concentration was constituted of two linear segments with different slopes that corresponded to two different ranges of substrate concentration. The increase in the amounts of CAP at the redox site indicated that the concentration of reaction centers will be less than the concentration of electroactive substrates at the electrode surface. Under this condition, a variation occurred in the slope of the calibration plot (decrease in sensitivity) that can be attributed to diffusion limitation [32]. A detection limit of $9.96 \times 10^{-9} \mu \mathrm{mol} / \mathrm{L}(3 \sigma)$ was determined using the IUPAC rules [44]. Table 2 compares this value with the values reported by other research groups.

The long term stability of the modified carbon paste electrode was also examined using cyclic voltammetry. The results showed that the modified electrode response remained stable with no significant change in the voltammetric signal during one month (data not shown). When cyclic

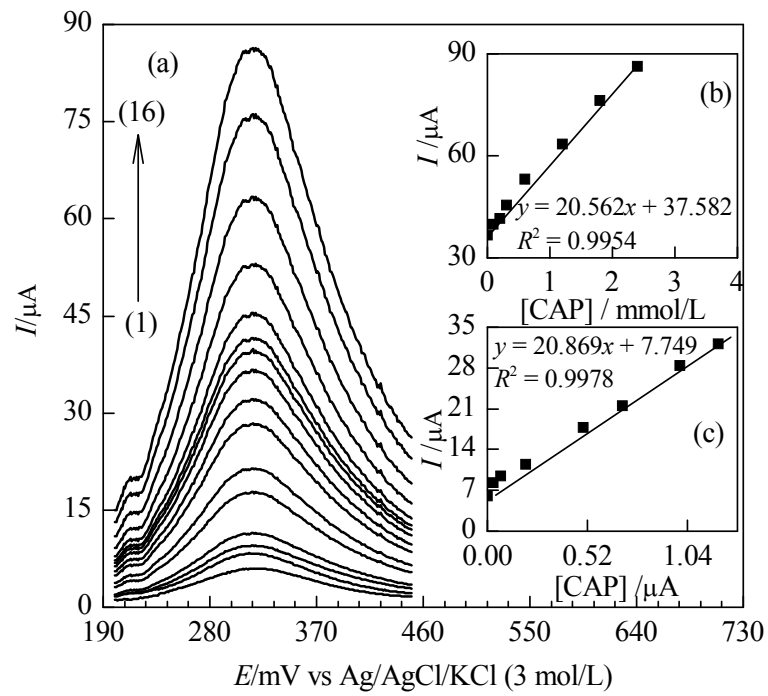

Fig. 6. (a) Square wave voltammograms with different concentrations of CAP: (1) 0.0, (2) 0.03, (3) 0.07, (4) 0.2, (5) 0.5, (6) 0.7, (7) 1.0, (8) 1.2 , (9) 5, (10) 90, (11) 200, (12) 300, (13) 600, (14) 1200, (15) 1800, and (16) $2400 \mu \mathrm{mol} / \mathrm{L}$ at the $\mathrm{FcCA} / \mathrm{TiO}_{2} / \mathrm{CPE}$ in $0.1 \mathrm{~mol} / \mathrm{L}$ phosphate buffer solution $(\mathrm{pH}=7.0)$. (b) and (c) plots of peak current versus various CAP concentration. SWV: amplitude, $25 \mathrm{mV}$; frequency, 15 $\mathrm{Hz}$. voltammograms were recorded after the electrode was stored in a dry atmosphere at room temperature, the peak potential for the oxidation of CAP was unchanged, and the oxidation current showed a $1.6 \%$ decrease relative to the initial response.

\subsection{Sample analysis}

\subsubsection{Determination of CAP in pharmaceutical and biological samples}

The use of the modified electrode for the voltammetric measurements of CAP was investigated by the determination of CAP in pharmaceutical (tablet, containing $150 \mathrm{mg}$ CAP) and real-life samples (urine sample). Each experiment was performed in triplicate by the standard addition method $(n=3)$. The urine samples taken from three different people were diluted 20 and 30 times with PBS before measurement. The accuracy of the proposed method was determined by spiking urine samples with different concentrations of CAP. The results obtained from our sensor for determining CAP in pharmaceutical and real samples are listed in Table 3. Good percentage recoveries of CAP were obtained from both samples (Table 3), proving the efficiency of the proposed sensor in the analysis of CAP in biological samples.

Table 3 Determination of CAP in biological and pharmaceutical samples

\begin{tabular}{|c|c|c|c|}
\hline Sample & $\begin{array}{l}\text { CAP added } \\
(\mu \mathrm{mol} / \mathrm{L})\end{array}$ & $\begin{array}{l}\text { CAP founded } \\
(\mu \mathrm{mol} / \mathrm{L})\end{array}$ & $\begin{array}{c}\text { Recovery } \\
(\%)\end{array}$ \\
\hline \multirow[t]{2}{*}{$1^{\mathrm{a}}$} & 0.0 & $20.0 \quad( \pm 0.05)$ & - \\
\hline & 2.0 & $21.96( \pm 0.02)$ & 99.82 \\
\hline \multirow[t]{2}{*}{$2^{\mathrm{a}}$} & 0.0 & $30.0 \quad( \pm 0.03)$ & - \\
\hline & 4.0 & $34.02( \pm 0.02)$ & 100.1 \\
\hline \multirow[t]{2}{*}{$3^{\mathrm{a}}$} & 0.0 & $40.0 \quad( \pm 0.03)$ & - \\
\hline & 6.0 & $45.98( \pm 0.04)$ & 99.95 \\
\hline \multirow[t]{2}{*}{$4^{b}$} & 0.0 & 0.0 & - \\
\hline & 2.0 & $1.97( \pm 0.04)$ & 98.5 \\
\hline \multirow[t]{2}{*}{$5^{b}$} & 0.0 & 0.0 & - \\
\hline & 4.0 & $3.98( \pm 0.03)$ & 99.5 \\
\hline \multirow[t]{2}{*}{$6^{\mathrm{b}}$} & 0.0 & $1.0 \quad( \pm 0.01)$ & - \\
\hline & 6.0 & $7.1 \quad( \pm 0.03)$ & 101.4 \\
\hline
\end{tabular}

${ }^{\mathrm{a}}$ Tablet sample.

${ }^{\mathrm{b}}$ Urine sample.

Table 2 Dynamic ranges and detection limits for the voltammetric determination of CAP at the various modified electrodes

\begin{tabular}{lccc}
\hline Electrode & Modifier & Dynamic range $(\mu \mathrm{mol} / \mathrm{L})$ & Limit of detection $(\mu \mathrm{mol} / \mathrm{L})$ \\
\hline Carbon paste & cobalt-5-nitrolsalophen & $4-110$ & 1.1 \\
GC & $\mathrm{MCNT} / \mathrm{HCF}$ & $0.5-600$ & 0.2 \\
Carbon paste & $\mathrm{FcCA}$ & $0.3-140$ & 0.091 \\
BDD & - & $0.5-100$ & 0.01 \\
Carbon paste & nano-TiO $/ \mathrm{FcCA}$ & $0.03-2400$ & {$[46]$} \\
\hline
\end{tabular}




\subsubsection{Interference studies}

The influence of foreign compounds which can be found in typical biological samples containing CAP was investigated by using solutions containing $10.0 \mu \mathrm{mol} / \mathrm{L}$ of the drug and adding various concentrations of the interfering compounds. The concentrations of the foreign substances were $0.1 \mathrm{~mol} / \mathrm{L}$ for $\mathrm{Na}^{+}, \mathrm{Cl}^{-}$, and $\mathrm{K}^{+}, 0.01 \mathrm{~mol} / \mathrm{L}$ for $\mathrm{Mg}^{2+}$ and $\mathrm{Ca}^{2+}$, and $0.01 \mathrm{~mol} / \mathrm{L}$ for glucose, 1-asparagines, glycine, phenylalanine and histidine. The tolerance limits were obtained by comparing the peak height with that obtained by injecting an aqueous solution of pure CAP. The measured signal variation was taken as $\pm 5 \%$. The absence of any significant shift in the peak currents recorded in the presence of the interfering species proved that the $\mathrm{FcCA} / \mathrm{TiO}_{2} / \mathrm{CPE}$ can operate as a sensor for the determination of CAP in biological samples. The limitation of the proposed sensor is the interference in complex samples that have electrochemically active species, such as plasma. Species such as glutathione and cysteine have a potential peak close to the potential peak of CAP and can cause errors. To solve this, the interfering species can be separated out by the HPLC technique. The determination of CAP in these samples using an $\mathrm{FcCA} / \mathrm{TiO}_{2} / \mathrm{CPE}$ can be done after the separation by HPLC.

\section{Conclusions}

A novel sensor was fabricated by mixing nano- $\mathrm{TiO}_{2}$, FcCA and graphite powder to form a paste composite, $\mathrm{FcCA} / \mathrm{TiO}_{2} / \mathrm{CPE}$. The $\mathrm{FcCA} / \mathrm{TiO}_{2} / \mathrm{CPE}$ exhibited high electrocatalytic activity for the oxidation of CAP in phosphate buffered solution $(\mathrm{pH}=7.0)$. The simple fabrication used to make the modified electrode is an obvious advantage of the proposed sensor. The SWV peak current increased linearly with the concentration of CAP in the range of 0.03-2400 $\mu \mathrm{mol} / \mathrm{L}$ with a very low detection limit of $0.0096 \mu \mathrm{mol} / \mathrm{L}$. These results are significant for practical applications. The experiments showed that the $\mathrm{FcCA} / \mathrm{TiO}_{2} / \mathrm{CPE}$ can be used for the determination of CAP in pharmaceutical and biological samples.

\section{References}

1 Cushman D W, Cheung H S, Sabo E F, Ondetti M A. Biochemistry, 1978, 16: 5484

2 Klein J, Colin P, Scherer E, Levy M, Koren G. Ther Drug Monit, 1990, 12: 105

3 Duchin K L, McKinstry D N, Cohen A L, Migdalof B H. Clin Pharmacokinet, 1988, 14: 241

4 Boyer J, Liu R H. Nutrition, 2004, 3: 1

5 Demirkol O, Adams C, Ercal N. J Agr Food Chem, 2004, 52:
8151

6 Arakawa M, Ushimaru N, Osada N, Oda T, Ishige K, Ito Y. Neurosci Res, 2006, 55: 255

7 Fang Y Z, Yang S, Wu G. Nutrition, 2002, 18: 872

8 Zhang X R, Baeyens W R G, Van der Weken G, Calokerinos A C, Nakashima K. Anal Chim Acta, 1995, 303: 121

9 Xinrong Z, Baeyens W R G, Van der Weken G, Calokerinos A C, Nakashima K. J Pharm Biomed Anal, 1995, 13: 425

10 Sastry C S P, Srinivas K R, Prasad K M M K. Anal Lett, 1996, 29: 1329

11 Askal H F. Talanta, 1991, 38: 1155

12 El-ashry S M, Ibrahim F A. Anal Lett, 1992, 25: 1657

13 Panderi I, Parissi-poulou M. Int J Pharm, 1992, 86: 99

14 Emara K M, Mohamed A M I, Askal H F, Darwish I A. Anal Lett, 1993, 26: 2385

15 Sastry C S P, Rao S G, Naidu P Y, Srinivas K R. Anal Lett, 1998, 31: 263

16 Squella J A, Lemus I, Borges Y, Nevgara-Vergara I J. Bol Soc Chilena Quim, 1992, 37: 259

17 de Oliveira I R W Z, Vieira I C. Enzyme Microbiol Technol, 2006, 38: 449

18 de Oliveira I R W Z, Fernandes S C, Vieira I C. J Pharm Biomed Anal, 2007, 40: 661

19 de Oliveira I R W Z, Os'orio R E-H M B, Neves A, Vieira I C. Sensor Actuat B, 2007, 122: 89

20 Stefan R I, van Staden J F, Aboul-Enein H Y. Talanta, 2000, 51: 969

21 Wakabayashi H, Yamato S, Nakajima M, Shimada K. J Pharm Biomed Anal, 1994, 12: 1147

22 Siangproh W, Ngamukot P, Chailapakul O. Sensor Actuat B, 2003, 91: 60

23 Ghicov A, Macak J M, Tsuchiya H, Kunze J, Haeublein V, Frey L, Schmuki P. Nano Lett, 2006, 6: 1080

24 Wang L, Bai J, Huang P, Wang H, Zhang L, Zhao Y. Electrochem Commun, 2006, 8: 1035

25 Navio J A, Cerrillos C, Pradera M A, Morales E, Gomez-Ariza J L. Langmuir, 1998, 14: 388

26 Ranjit K T, Willner I. J Phys Chem B, 1998, 102: 9397

27 Chang C P, Chen J N, Lu M C, Yang H Y. Chemosphere, 2005, 58: 1071

28 Kim S B, Hong S C. Appl Catal B, 2002, 35: 305

29 O’Regan B, Gratzel M. Nature, 1991, 353: 737

30 Macak J M, Barczuk P J, Tsuchiya H, Nowakowska M Z, Ghicov A, Chojak M, Bauer S, Virtanen S, Kulesza P J, Schmuki P. Electrochem Commun, 2005, 7: 1417

31 Raoof J B, Ojani R, Baghayeri M. Sensor Actuat B, 2009, 143: 261

32 Bard A J, Faulkner L R. Electrochemical Methods, Fundamentals and Applications. New York: Wiley, 2001

33 Dong S J, Che LG, Xie Y W. Chemical Modified Electrode. Beijing: Science Press, 2003

34 Raoof J B, Ojani R, Chekin F. Electroanalysis, 2007, 19: 1883

35 Raoof J B, Ojani R, Kolbadinezhad M. J Solid State Electrochem, 2009, 13: 1411 
36 Raoof J B, Ojani R, Chekin F. J Chem Sci, 2009, 121: 1083

37 Raoof J B, Ojani R, Kiani A. J Electroanal Chem, 2001, 515: 45

38 Zhou M, Ding J, Guo L, Shang Q. Anal Chem, 2007, 79: 5328

39 Beitollahi H, Raoof J B, Hosseinzadeh R. Electroanalysis, 2011, 23: 1934

40 Pournaghi-Azar M H, Razmi-Nerbin H. J Electroanal Chem, 2000, 488: 17

41 Kuo K N, Murray R W. J Electroanal Chem, 1982, 131: 37

42 Galus Z. Fundamentals of Electrochemical Analysis. New
York: Ellis Horwood, 1976

43 Wang J. Analytical Electrochemistry. 2nd Ed. New York: Wiley, 2000

44 Vaughan N P, Milligan B D, Ogden T L. Analyst, 1987, 112: 199

45 Shahrokhian S, Karimi M, Khajehsharifi H. Sensor Actuat B, 2005, 109: 278

46 Rezaei B, Damiri S. Sensor Actuat B, 2008, 134: 324

47 Karimi-Maleh H, Ensafi A A, Allafchian A R. J Solid State Chem, 2010, 14: 9 